\title{
CYTODIAGNOSTIC SPECTRUM OF METASTATIC LYMPH NODES - A PROSPECTIVE STUDY
}

\author{
Samarpita Nama1, Nabaneet Majumder2, Sanjay Nath³, Ganes Chandra Hati, Habibul Islam ${ }^{5}$ \\ ${ }^{13}$ rd Year Postgraduate Trainee, Department of Pathology, Tripura Medical College and Dr. BRAM Teaching Hospital, Agartala. \\ ${ }^{2}$ Assistant Professor, Department of Pathology, Tripura Medical College and Dr. BRAM Teaching Hospital, Agartala. \\ ${ }_{3}^{3}$ Professor, Department of Pathology, Tripura Medical College and Dr. BRAM Teaching Hospital, Agartala. \\ 4 Professor, Department of Pathology, Tripura Medical College and Dr. BRAM Teaching Hospital, Agartala. \\ ${ }_{5}^{5}$ Professor and HOD, Department of Pathology, Tripura Medical College and Dr. BRAM Teaching Hospital, Agartala.
}

\section{ABSTRACT}

\section{BACKGROUND}

Malignancies in lymph nodes in our country are mostly metastatic in nature and sometimes constitute the first clinical manife station of the disease with an incidence ranging from $65.7 \%$ to $80.4 \%$ and lymphomas from $2 \%$ to $15.3 \%$ among lymph nodes aspirated from all sites. Enlarged lymph nodes are often easily accessible, which makes Fine Needle Aspiration Cytology (FNAC) a very simple and important diagnostic tool for lymph node lesions.

\section{MATERIALS AND METHODS}

Fine Needle Aspiration Cytology (FNAC) is a very simple and rapid diagnostic tool. The present study is a prospective cross-sectional over a period of 2 years from June 2014 to May 2016 to find out cytodiagnosis of clinically suspected malignant lymphadenitis.

\section{RESULTS}

A total of 150 cases clinically suspected for malignancy were evaluated, out of which 121 (80.66\%) were metastatic and rest 4 (2.66\%) cases were lymphoma and 25 (16.66\%) cases turned out to be reactive lymph nodes and benign cystic and were excluded from the study for further analysis. The peak age of incidence of metastatic lymphadenitis was in the 5 th decade amounting to 58 (47.93\%) cases followed by 6th and 4th decade with an age range varying from 23 to 84 years with a male-to-female ratio of $2.78: 1$. Out of these 121 cases, 76 (62.80\%) were metastatic Squamous Cell Carcinoma (SCC) followed by adenocarcinoma in 27 cases (22.31\%), breast carcinoma in 6 (4.95\%), small cell carcinoma of lung and undifferentiated carcinoma in 5 cases each (4.13\%) and papillary carcinoma of thyroid in 2 (4.95\%). The maximum number of lymph nodes involved were the cervical group in 98 (80.99\%) followed by axillary in 9 (7.43\%), supraclavicular in 9 (7.43\%) inguinal in $4(3.30 \%)$ and mesenteric in $1(0.82 \%)$ case. The primary tumours could be identified in 110 out of 121 cases of metastatic lymphadenitis. The common sites were head and neck region, nasopharynx, other parts of GIT, breast, lung and genital areas.

\section{CONCLUSION}

It has been concluded that FNAC helps in diagnosing and categorisation of the tumour type, while detailed clinical history and investigations help in identifying the primary tumour site and further management.

\section{KEYWORDS}

Fine Needle Aspiration Cytology (FNAC), Cytodiagnosis, Metastatic Malignancy, Metastatic Lymphadenitis.

HOW TO CITE THIS ARTICLE: Nama S, Majumder N, Nath S, et al. Cytodiagnostic spectrum of metastatic lymph nodes - a prospective study. J. Evolution Med. Dent. Sci. 2016;5(103):7554-7558, DOI: 10.14260/Jemds/2016/1711

\section{BACKGROUND}

The Fine Needle Aspiration Cytology (FNAC) is one of the most commonly practised investigative procedures for the diagnosis of various conditions including metastatic malignancies. In 1930, Martin and Ellis of Memorial Hospital for Cancer included tumours that had metastasised to lymph node among targets of aspiration biopsy. ${ }^{1}$ Since then, it is a well-established and accepted method because of simplicity of the procedure, easy repeatability if necessary, a very reasonable sensitivity and specificity, fast and cost effectiveness with very minimal complications if at all.

Financial or Other, Competing Interest: None.

Submission 05-12-2016, Peer Review 18-12-2016,

Acceptance 20-12-2016, Published 26-12-2016.

Corresponding Author:

Dr. Samarpita Nama,

$3^{\text {rd }}$ Year Postgraduate Trainee,

Department of Pathology,

Tripura Medical College and Dr. BRAM Teaching Hospital,

Agartala.

E-mail:msamarpita15@gmail.com

DOI: $10.14260 /$ jemds $/ 2016 / 1711$

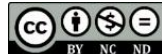

FNAC not only confirms the presence of metastatic disease, but also gives the clue regarding the nature and origin of primary malignancy. It is useful for the detection of recurrence and new metastases. Hence, it is a very good tool in followup of malignant conditions as well. Although, histopathological examination is considered as the gold standard in diagnosis, especially in lymphomas, FNAC may be the only tool for diagnosis and further management of the patients in some instances of metastatic malignancy.

In developing country like India, infective lymphadenopathy is also quite common, mostly due to high prevalence of tuberculosis and other granulomatous conditions. However, still a large percentage of cervical lymphadenopathy in adults turn out to be cysts or abscesses, benign and malignant conditions may mimic lymph node metastasis, especially with a case of known tumour. ${ }^{2}$ Hence, clinical recognition and urgent diagnosis of palpable lymphadenopathy is of immense importance, especially to differentiate between inflammatory or metastatic or primary neoplastic lesion. The present study undertaken at Tripura Medical College and Dr. BRAM Teaching Hospital from June 2014 to May 2016 (2 years) was to unravel the spectrum of 
cytomorphological patterns of metastatic lymph nodes in different areas of the body in this part of country.

\section{MATERIALS AND METHODS}

Study design was a prospective and a cross-sectional one. The duration of the study was 2 years from June 2014 to May 2016. The study was approved by Institutional Ethics Committee of Tripura Medical College and Dr. BRAM Teaching Hospital, Hapania.

All patients with metastatic lymphadenopathy reported from Dept. of Pathology, TMC and Dr. BRAM Teaching Hospital was analysed for the study. An informed consent of all the patients has been taken and the pros and cons of the said procedure were explained to the patients and their guardians.

A detailed history, clinical examination and relevant investigations were documented. Under aseptic precaution, node was held between left index finger and thumb followed by insertion of 22 - 23 gauge needle fitted with $10 \mathrm{~mL}$ syringe for aspiration. The needle with syringe was introduced in node, plunger of syringe pulled to create negative pressure. With the negative pressure, maintained needle was moved to and fro within node to aspirate the material. The negative pressure was released and needle with syringe was withdrawn from node. Pressure with cotton swab was applied to node after withdrawal of needle. Needle was detached from syringe, air drawn into syringe, needle reattached and material pushed on slides. Multiple smears were made; few of them air dried for Romanowsky stain like May-Grunwald-Giemsa stain (MGG), Leishman Giemsa and few were fixed with ethyl alcohol for staining with Haematoxylin and Eosin (H and E) stain and Periodic-Acid Schiff (PAS) stain. Special stain such as Ziehl-Neelsen's stain (Z-N) was used wherever indicated.

In few cases where the glands were deeper and accessibility was difficult, Ultrasonography (USG) guided FNAC was performed. All the clinical and pathological data were collected and analysed.

\section{RESULTS}

A total of 150 cases clinically suspected for malignancy were evaluated, out of which 121 (80.66\%) were metastatic tumours of lymph node. Rest 4 (2.66\%) cases were lymphoma and $25(16.66 \%)$ cases clinically suspected for malignancy turned out to be reactive lymph nodes and benign cystic lesions and were finally excluded from our study.

\begin{tabular}{|c|c|c|c|}
\hline Sl. No. & Age Group(yrs.) & No. & Percentage (\%) \\
\hline 1 & $21-30$ & 2 & 1.65 \\
\hline 2 & $31-40$ & 11 & 9.09 \\
\hline 3 & $41-50$ & 19 & 15.70 \\
\hline 4 & $51-60$ & 58 & 47.93 \\
\hline 5 & $61-70$ & 25 & 20.66 \\
\hline 6 & $71-80$ & 4 & 3.30 \\
\hline 7 & $81-90$ & 02 & 1.65 \\
\hline Total & \multicolumn{3}{|c|}{ 121 } \\
\hline \multicolumn{4}{|c|}{ Table 1. Age Distribution } \\
\hline
\end{tabular}

The peak age of incidence of metastatic lesions were in the 5 th decade amounting to $58(47.93 \%)$ cases followed by 6 th and 4th decades in $25(20.66 \%)$ and $19(15.70 \%)$ respectively. The youngest and oldest patient of our study was 23 years and 84 years respectively (Table 1 ).

\begin{tabular}{|c|c|c|c|}
\hline Sex & No. & Percentage (\%) & Ratio \\
\hline Male & 89 & 73.55 & \multirow{2}{*}{$2.78: 1$} \\
\cline { 1 - 3 } Female & 32 & 26.44 & \\
\hline \multicolumn{4}{|c|}{ Table 2. Sex Distribution } \\
\hline
\end{tabular}

Males outnumber the females in our study amounting to $89(73.55 \%)$ and $32(26.44 \%)$ cases respectively, with a maleto-female ratio of 2.78:1 (Table 2).

\begin{tabular}{|c|c|c|}
\hline Type of Malignancy & $\begin{array}{l}\text { No. of } \\
\text { Cases }\end{array}$ & $\begin{array}{c}\text { Percentage } \\
(\%)\end{array}$ \\
\hline Squamous cell carcinoma & 76 & 62.80 \\
\hline Adenocarcinoma & 27 & 22.31 \\
\hline Breast carcinoma & 6 & 4.95 \\
\hline Small cell carcinoma & 5 & 4.13 \\
\hline $\begin{array}{l}\text { Undifferentiated } \\
\text { carcinoma }\end{array}$ & 5 & 4.13 \\
\hline $\begin{array}{l}\text { Papillary carcinoma of } \\
\text { thyroid }\end{array}$ & 02 & 1.65 \\
\hline Total & 121 & 100 \\
\hline \multicolumn{3}{|c|}{$\begin{array}{l}\text { Table 3. Distribution of Pathological Subtypes of } \\
\text { Metastatic in Lymph Nodes }\end{array}$} \\
\hline
\end{tabular}

Out of these 121 cases, $76(62.80 \%)$ were metastatic Squamous Cell Carcinoma (SCC) followed by adenocarcinoma in 27 cases $(22.31 \%)$. The rest of the cases were breast carcinoma in 6 (4.95\%), small cell carcinoma of lung and undifferentiated carcinoma in 5 cases each (4.13\%) and Papillary carcinoma of thyroid in 2 (4.95\%) (Table 3, Fig. 1 6).

\begin{tabular}{|c|c|c|c|c|}
\hline$\stackrel{ \pm}{\Delta}$ & 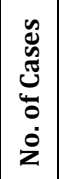 & 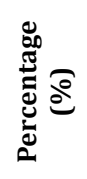 & 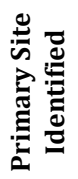 & 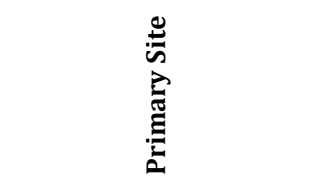 \\
\hline Cervical & 98 & 80.99 & 89 & $\begin{array}{l}\text { Head and neck, lung, } \\
\text { nasopharynx, other parts } \\
\text { of GIT, breast, thyroid }\end{array}$ \\
\hline Axillary & 9 & 7.43 & 8 & Breast and lung \\
\hline Supraclavicular & 9 & 7.43 & 8 & GIT, lung, breast \\
\hline Inguinal & 4 & 3.30 & 4 & Vulva, penis, cervix \\
\hline $\begin{array}{l}\text { Mesentery } \\
\text { primary site } \\
\text { unknown }\end{array}$ & $\begin{array}{c}1 \\
11\end{array}$ & 0.82 & $\begin{array}{c}1 \\
11\end{array}$ & GIT \\
\hline Total & 121 & 100 & 121 & \\
\hline \multicolumn{5}{|c|}{$\begin{array}{l}\text { Table 4. Metastatic Sites showing } \\
\text { the Origin of Primary Tumours }\end{array}$} \\
\hline
\end{tabular}

The maximum number of lymph nodes involved were the cervical group in $98(80.99 \%)$ followed by axillary in 9 (7.43\%), supraclavicular in 9 (7.43\%), inguinal in $4(3.30 \%)$ and mesenteric in $1(0.82 \%)$ case.

The primary site of lesions could be identified in 110 out of 121 cases of metastatic lymphadenitis. The common sites were head and neck region, nasopharynx, other parts of GIT, breast, lung and genital areas. In spite of repeated search in 7 cases of cervical, 2 cases of axillary and one case of supraclavicular lymphadenitis we failed to find out the primary tumour. 


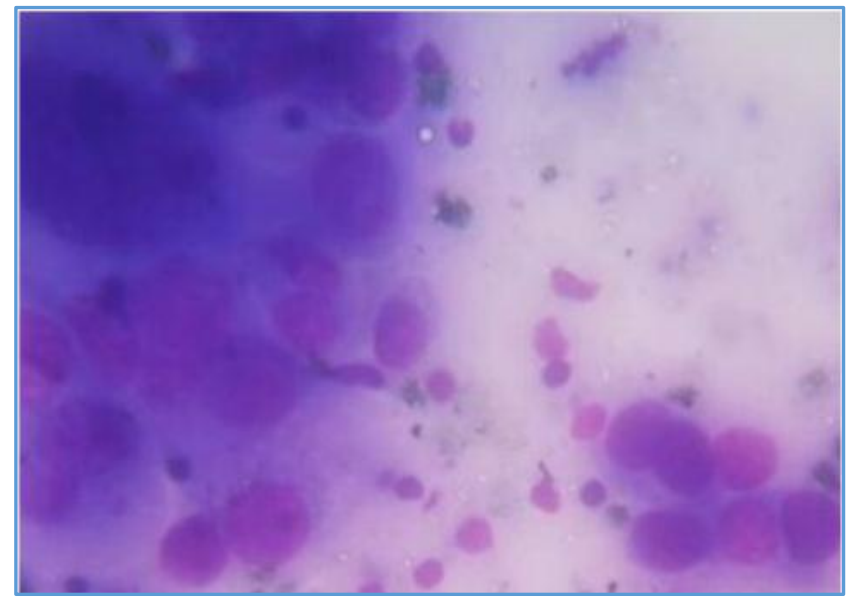

Figure 1. Metastatic Squamous Cell Carcinoma showing Clear Blue Cytoplasmic Staining, indicating Squamous Differentiation (May-Grunwald-Giemsa: 40X)

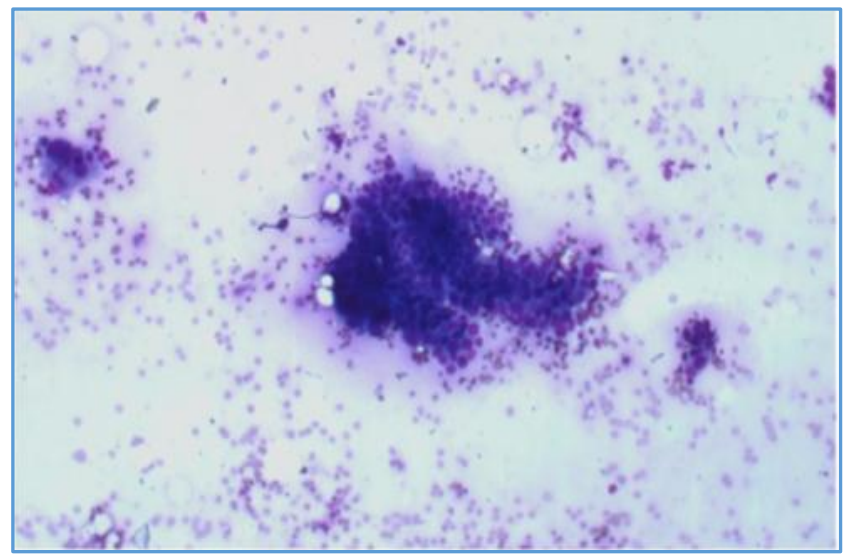

Figure 2. Metastatic Adenocarcinoma showing Glandular Cells, Pleomorphic in Nature and Arranged in Monolayer Sheets (May-Grunwald-Giemsa: 40X)

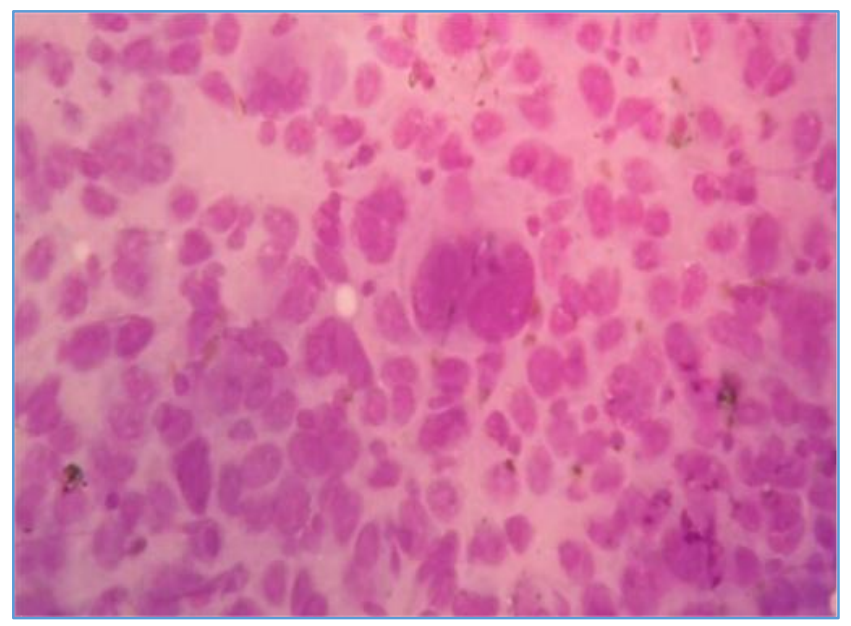

Figure 3. Metastatic Undifferentiated Carcinoma showing Pleomorphic Cell Populations with High Nuclear Cytoplasmic Ratio. Background shows Mature Lymphocytes (Leishman Giemsa; 40X)

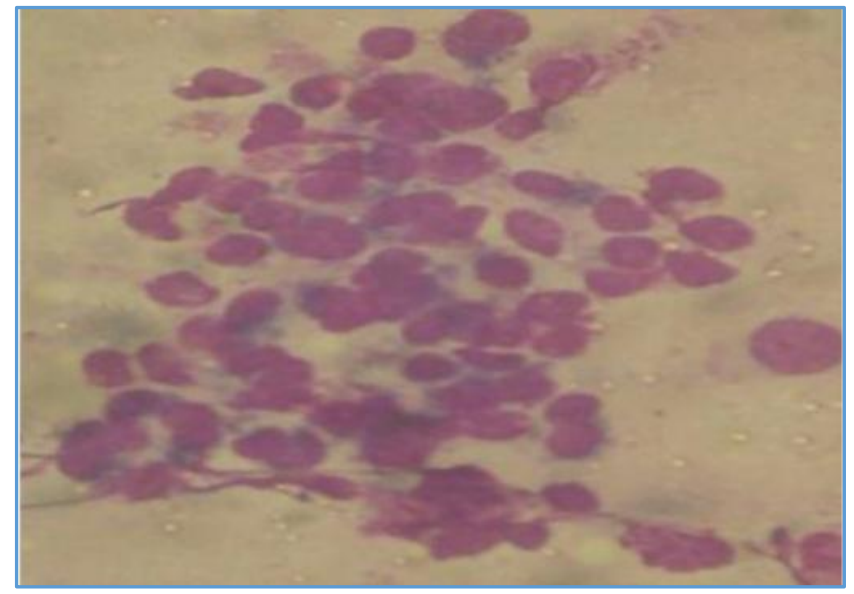

Figure 4. Cytological Smear showing Metastatic Small Cell Carcinoma: (May-Grunwald-Giemsa 40X)

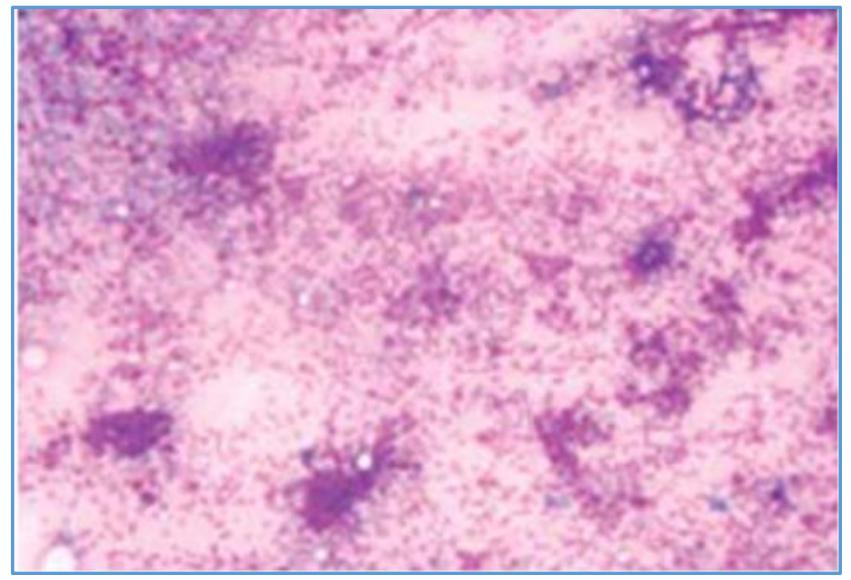

Figure 5. Cytological Smear showing Malignant Ductal Cells with Lymphoid Cells in the Background

(Giemsa Stain: 40X)

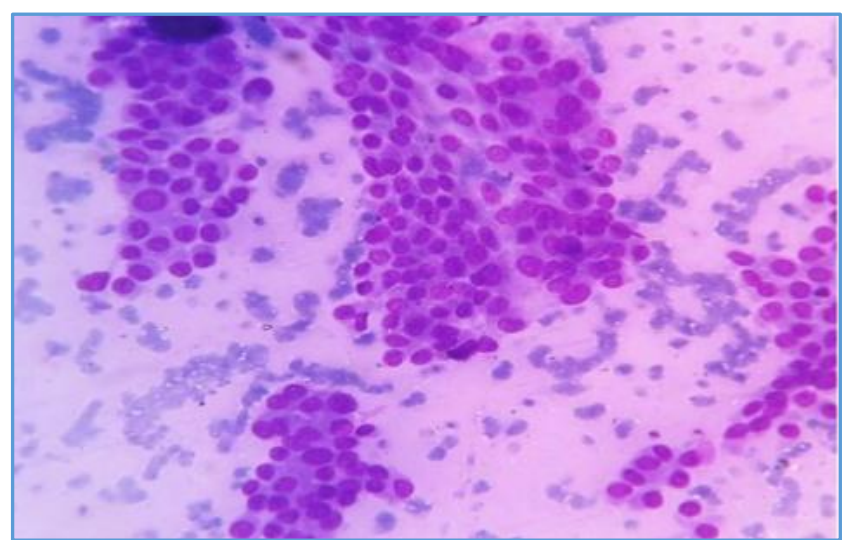

Figure 6. Cytological Smear of Metastatic Papillary Carcinoma of Thyroid showing Papillary Pattern and Nuclear Grooving (May-Grunwald-Giemsa: 10X)

\section{DISCUSSION}

Malignancies in lymph nodes in our country are mostly metastatic in nature with an incidence ranging from $65.7 \%{ }^{2}$ to $80.4 \%^{3}$ and lymphomas from $2 \% 4$ to $15.3 \%^{3}$ among lymph nodes aspirated from all sites. So, lymph node aspiration plays a very vital role in the diagnosis of malignant lymphadenopathies, especially in a developing country like India considering the economic and health scenario. 
The diagnosis given by FNAC is often the only diagnosis accepted and there is no further correlation with histopathology, especially in cases of advanced malignancies which provides clues for occult primaries. FNAC sometimes also surprises the physician, where there were no clues to suspect a malignant condition at all.

Our study showed metastatic malignancy of lymph nodes to be $80.66 \%$ and lymphomas in $2.66 \%$. This observation very closely correlates with other Indian studies by Alam K et al ${ }^{3}$ and Khajuria $\mathrm{R}$ et $\mathrm{al},{ }^{4}$ who also confirmed that metastatic malignancy of lymph nodes were far more commoner than lymphomas, although there were variations in the percentage involved depending on the number of cases studied. However, little deviations were also observed in comparison with another Indian study by Arora B et al, 5 where they documented little higher number lymphomas as compared to our study. It was noted that metastases and lymphomas were $68 \%$ and $32 \%$ respectively. A published data on the same from Brazilians revealed as $79.4 \%$ metastases and $14.2 \%$ lymphomas. ${ }^{6}$

The peak age of incidence was in the 5 th decade followed by 6 th and 7 th decades. It correlates with the study by Kamat GC. ${ }^{7}$

In our study, the frequency of malignancies in males outnumber the females with a male-to-female ratio of 2.78:1. This may be due to higher prevalence of different addictions in males than their female counterparts, which are suspected to be one of leading causes of malignancy. Similar observations were made by Haque and Talukder ${ }^{8}$ and Steel et al. ${ }^{9}$

The cervical groups of lymph nodes were the most common group of lymph nodes to be involved in the present study and the primary is mostly noted from the oral cavity and other parts of upper GIT. Similar observations were noted by Hirachand et al ${ }^{10}$ and Hoft $S$ et al. 11

The commonest cytodiagnosis were squamous cell carcinoma followed by adenocarcinoma. Squamous cell carcinoma was also highest in cervical group of lymph nodes, as majority of suspected nodes were in the cervical group of nodes as well. Similar observations noted by Alam $\mathrm{K}$ et $\mathrm{al}^{3}$ and Hoft $S$ et al. ${ }^{11}$

Rates of malignancy in oral cavity/pharynx, oesophagus and male larynx are highest in India, probably due to the use of multiple tobacco products as reported by Rastogi T et al. ${ }^{12}$ Also our study is based in North Eastern part of the country, where chewing habits of tobacco and beetle nuts are quite high.

Metastatic squamous cell carcinoma was predominantly seen in 5 th decade of life, whereas metastatic adenocarcinoma does not show any specific age dominance which correlates with the previous studies.3,4 On the contrary to our observations, few other studies where metastatic adenocarcinoma was the most common subtype than squamous cell carcinoma.13,14 However, often it becomes difficult to distinguish between adenocarcinoma and poorly differentiated squamous cell carcinoma when the cell clusters show thick nuclear membrane and prominent nucleoli.

Also, as over all male predominance is noted in metastatic tumours in the present study, which reflects in case of metastatic squamous carcinoma as well. Similar observations were documented by Khajuria $\mathrm{R}$ et $\mathrm{al}^{4}{ }^{4}$ Qadri SK et al ${ }^{13}$ and Mohanty R et al. ${ }^{14}$

The primary sites of tumours in each group of enlarged suspected malignant lymph nodes in our study correlated well with other similar studies.2,15 A detailed history, radiological investigations and immunohistochemistry in difficult cases may help to arrive at a definitive diagnosis. ${ }^{15}$

The improved diagnostic accuracy of FNAC in the diagnosis of malignant lesions of the lymph nodes is probably due to a combination of factors, such as availability of using and guidance of imaging technique as well many other cytodiagnostic assistances like immunohistochemistry, trained and qualified manpower over the years.

\section{CONCLUSION}

The present study highlights cytological spectrum of metastatic lesions presenting as lymphadenopathy over a period of 2 years at the Department of Pathology, TMC and Dr. BRAM Teaching Hospital. FNAC is a very convenient extension of the more invasive biopsy procedure, lending itself to saving of time and cost, and a better compliant procedure for both patients and physicians in the management and followup of lymphadenopathies. FNAC helps in diagnosing and categorisation of the tumour type, while detailed clinical history and investigations help in identifying the primary tumour site and further management.

\section{REFERENCES}

1. Nancy C, Katz R. Lymph Nodes. Chapter 31. Koss diagnostic cytology and its histologic basis. $5^{\text {th }}$ edn. Vol-2. Lippincott Williams \& Wilkins 2005:1786-1928.

2. Bagwan IN, Kane SV, Chinoy RF. Cytologic evaluaton of the enlarged neck node: FNAC utility in metastatic neck diseases. Int J Pathol 2007;6:2.

3. Alam K, Khan A, Siddiqui F, et al. Fine needle aspiration cytology (FNAC): a handy tool for metastatic lymphadenopathy. Int J Pathol 2010;10:2.

4. Khajuria R, Goswami KC, Singh K, et al. Pattern of lymphadenopathy on fine needle aspiration cytology in Jammu. JK Sci 2006;8(3):157-9.

5. Arora B, Beena KR, Arora DR. Utility of fine needle aspiration cytology in lymphadenopathies. J Cytol. 1999;16:61-6.

6. Martins MR, Santos GC. Fine-needle aspiration cytology in the diagnosis of superficial lymphadenopathy: a 5-year Brazilian experience. Diagn Cytopathol 2006;34(2):1304.

7. Kamat GC. A ten year histopathological study of generalised lymphadenopathy in India. S Afr Fam Pract 2011;53(3):267-70.

8. Haque MA, Talukder SI. Evaluation of fine needleaspiration cytology (FNAC) of lymph node in Mymensingh. Mymensingh Med J 2003;12(1):33-5.

9. Steel BJ, Schwartz MR, Ramzy I. Fine needle aspiration biopsy in the diagnosis of lympladenopathy in 1,103 patients. Role, limitations and analysis of the diagnostic pitfalls. Acta Cytol 1995;39(1):76-81. 
10. Hirachand S, Lakhey M, Akhter P, et al. Evaluation of fine needle aspiration cytology of lymph nodes in Kathmandu medical college, teaching hospital. Kathmandu Univ Med J 2009;7(26):139-42.

11. Hoft S, Muhle C, Brenner W, et al. Fine-needle aspiration cytology of the sentinel lymph node in head and neck cancer. J Nucl Med 2002;43(12):1585-90.

12. Rastogi $T$, Devesa $S$, Mangtani $P$, et al. Cancer incidence rates among South Asians in four geographic regions: India, Singapore, UK and US. Int $\mathrm{J}$ Epidemiol 2008;37(1):147-60.
13. Qadri SK, Hamdani NH, Shah $P$, et al. Profile of lymphadenopathy in Kashmir valley: a cytological Study. Asian Pacific J Cancer Prev 2012;13:3621-5.

14. Mohanty R, Wilkinson A. Utility of fine needle aspiration cytology of lymph nodes. IOSR Journal of Dental and Medical Sciences 2013;8(5):13-8.

15. Gupta N, Rajwanshi A, Srinivasan R, et al. Pathology of supraclavicular lymphadenopathy in Chandigarh, north India: an audit of 200 cases diagnosed by fine needle aspiration. Cytopathology 2006;17(2):94-6. 